\title{
Evaluation of Social Media Channel Preference for Student Engagement Improvement in Universities Using Entropy and Topsis Method
}

\author{
Meyliana $^{1}$, Achmad Nizar Hidayanto ${ }^{2}$, Eko Kuswardono Budiardjo ${ }^{2}$ \\ ${ }^{1}$ Bina Nusantara University, ${ }^{2}$ Universitas Indonesia (Indonesia) \\ meyliana@binus.edu,nizan@,cs.ui.ac.id,elko@,cs.ui.ac.id
}

Received: August 2015

Accepted: November 2015

\section{Abstract:}

Purpose: To analyze students' social media preference in order to improve student engagement with university by examining social media implementation quality in terms of information and service quality.

Design/methodology/approach: Research methodology is started with the hierarchy creation of student engagement with university which then translated into questionnaire. This questionnaire was distributed to 58 universities in Jakarta (Indonesia's capital). The questionnaire result was analyzed with entropy and TOPSIS method.

Findings: In social media implementation quality, information quality is more important than service quality because in social media, a good information quality is really relevant with the usefulness and comprehensiveness of the information. On the other hand regarding service quality, the system availability will help students in their interaction process with university, on top of the service's efficiency and fulfillment. This directly impacts the cooperation between students, active learning process, and students' expectation. The social medias students preferred to improve student engagement with universities respectively are LINE, Facebook, Twitter, Wiki, Blog, Instagram, YouTube, Path, LinkedIn, and Podcast. 
Research limitations/implications: Social media's role is not only to create student engagement in the learning process, but also other aspects included by Chickering \& Gamson (1987).

Practical implications: The Social CRM channel shift from electronic into social media shows that social media holds an important role for university since it eases up the communication between university and the students. The good social media management has been an issue that needs to be solved by university by creating a unit or delegate a person that can manage the social media correctly and quickly so the students feel that they get the good service they want.

Originality/value: The other researches focus on observing social media influence to improve student engagement, but only in the context of learning process. This research observes social media roles in student engagement thoroughly according to the existing good practice. This research can also shows the order of social media that are seen important to create student engagement.

Keywords: Social media, student engagement, university, social CRM, entropy, TOPSIS

\section{Introduction}

Recently, internet has developed tremendously, and almost all business sector requires internet to use their business platform. Internet allows all organizations and individuals to connect without time and distance limitation. One of the technology tools that utilizes internet and has phenomenally developed is social media (Askool \& Nakata, 2010; Greenberg, 2010). Social media allows everyone to connect with each other and communicate with ease. With social media, we can even find old friends or relatives that are separated by distance and time zone. Its easy-to-use and user-friendly nature makes users addicted to keep using it. The social media usage in business organization activities is now commonly seen, especially in two ways communications such as collaboration, sharing between users, and creativity empowerment. The social media development or widely known as Web 2.0 allows sharing, collaboration, participation, and information distribution function to be done widely and massively (Patel, 2013). The innovation of social media usage has change the way organizations manage their relationship with customers or also known as Customer Relationship Management (CRM). Traditional CRM or CRM 1.0 is used more to manage customer information and make business decision (Mohan, Choi, \& Min, 2008; Greenberg, 2010). In CRM 1.0, communication is done one way, making the organization become the ecosystem central that focuses only on internal operational approach to manage the relation with customer effectively, or also known as customer management (Greenberg, 2010). Social media has shifter the way organizations manage their customer where 
organization prioritizes the customers more. Customers not only become information customers, but also involved in the product creation process. This happens because social media users has changed customers' behavior, where they are can free and easily communicate with organization in form of giving inputs, complaining, etc, emphasizing customer engagement (Greenberg, 2010; Malthouse, Haenlein, Skiera, Wege \& Zhang, 2013; Mosadegh \& Behboudi, 2011). This concept makes the shift from CRM 1.0 into CRM 2.0 or also known as Social CRM. Greenberg (2010) shows that Social CRM has given positive effects, especially in creating customer-based business value directly, not just being valuekeeping center. This Social CRM is also viable to service sector such as university where Social CRM should be utilized more to improve student engagement (Seeman \& O'Hara, 2006; Tapp, Hicks, \& Stone, 2004).

Currently, universities in Indonesia use social media without paying attention to their students preference and good social media management. The observation on 58 private universities in Jakarta on their official social media management embedded at their official website shows non-optimal results (Meyliana, Hidayanto, \& Budiardjo, 2015). The results are:

1. Generally, they only run Facebook $(100 \%)$, Twitter $(70,69 \%)$, LinkedIn $(84,48 \%)$, and YouTube $(51,72 \%)$. Those are decided directly by the universities without looking at their students' preference.

2. The activities conducted in the social medias are only even information sharing, not something that can increase student engagement with the university.

3. There's no one who exclusively delegated to manage social media, thus not increasing the social media management quality.

So far, there were some researches to see the social media role in student engagement, but only in active learning perspective. Chickering and Gamson (1987) in their research has created 7 good student engagement practice principles in undergraduate education, which are encouraging student-faculty contact, encouraging cooperation among students, encouraging active learning, giving prompt feedback, emphasizing time on task, communicating high expectations, and respecting diverse talents and ways of learning. If these 7 principles is accomplished, the student engagement will improve. Social media holds an important role to create student engagement improvement since students nowadays are Y-generation who are heavily social media-minded. Social media can mediate the communication among students and students with lecturer quickly and easily with chatting, discussion forum, and other features. Social media role in active learning has been discussed a lot of time in previous researches, including the role of Facebook and Twitter in supporting e-learning in university, social media role in integrated learning management system, etc (Bofin, 2013; Bosch, 2009; Ford, Bowden \& Beard, 2011; Glowatz \& Bofin, 2014; Glowatz \& O'Brien, 2013; Junco, Elavsky, \& Heiberger, 2012; Mazer, Murphy, \& Simonds, 2007; Muñoz \& Towner, 2009; Schouten, 
2011). Students can give feedback and express their expectation quickly via social media to university by writing on wall, sending message, etc. Lecturers can also motivate their students, and students can also motivate each other on effective time management, personal learning method, and embracing the diversity that can increase students' knowledge. All can be done virtually in social media via the features such as status reply, sticker sending, etc.

This research uses the approach from DeLone and McLean model of information system success, which is information quality and service quality as the criteria (DeLone \& McLean, 2003) that can be adapted into various needs, including social media. In the previous researches regarding information system management, including social media in creating satisfaction and loyalty dimension which in the end creates engagement, social media is a part of information system since it's an internet-based application created to facilitate active interaction between its users (Khan, 2013; Wise \& Shorter, 2014). According to Wise and Shorter (2014), social media is the collective of online communications channels dedicated to community-based input, interaction, content-sharing, and collaboration.

This motivates this research to dig deeper on social media management as Social CRM channel that is heavily required by universities to manage their student management and to find more about students' social media preference to increase the student engagement. Thus, this research has research question to be answered, which are:

1. How universities manage a good social media to increase the student engagement?

2. What social media that is preferred by the students to increase student engagement in universities?

\section{Theoretical and Evaluation Framework}

\subsection{Evaluation Framework}

This research has research steps and defined as evaluation framework (see Figure 1). It's started with deciding study subject, which is about social media usage to increase student engagement on university. After the study subject is determined, the next step is goal-setting. And then criteria and sub-criteria determining, followed by deciding alternatives. The next step is creates the overall hierarchy and makes it into a questionnaire. And then the questionnaire is distributed, followed by data analysis in the last step. The data analytic is conducted with 2 methods: counting the value with entropy method and rank the alternatives with TOPSIS method (Technique of Order Preference by Similarity to Ideal Solution). After that, then comes a conclusion regarding all of this research's results. In the next subsection, we explain all decision hierarchy created, from goal-setting to social media alternatives selection. 


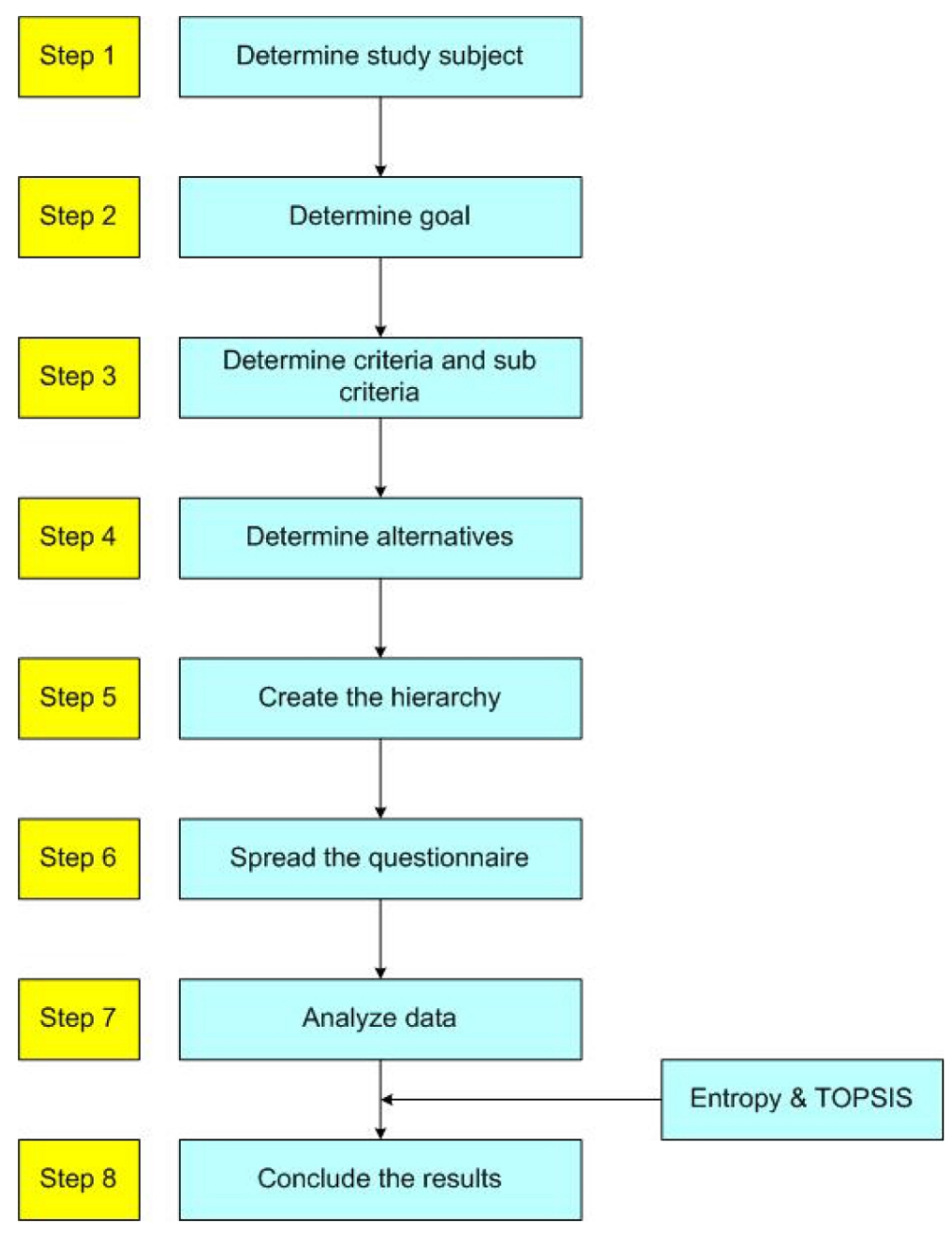

Figure 1. Evaluation Framework

\subsection{Goal, Criteria, Sub Criteria, Alternatives and Hierarchy}

\subsubsection{Goal}

The goal of this research is to find out "Social media usage preference to improve student engagement with university."

To achieve this goal, definitions that support this goal are required.

\subsubsection{Social Media}

Social media is a group of internet-based application that builds ideology foundation and Web 2.0 technology, and allows User Generated Content (UGC) creation and trading. There are several types of social media, including the likes of Wikipedia, YouTube, Facebook, and Second Life (Kaplan \& Haenlein, 2010). According to Doyle (2012), social media is an online 
technology tool that allows people to communicate easily via internet to share information and resources. Social media can be created and enjoyed in form of text, audio, video, picture, podcast, and other multimedia communication.

\subsubsection{Student Engagement}

Student engagement is an important component in student life cycle, from registering, being a freshmen, learning as a student, until graduated (Christenson, Reschly \& Wylie, 2012; Finn \& Zimmer, 2012; Rumberger \& Rotermund, 2012; Lawson \& Masyn, 2015). According to Trowler (2010), student engagement is concerned with the interaction between the time, effort and other relevant resources invested by both students and their institutions intended to optimise the student experience and enhance the learning outcomes and development of students and the performance, and reputation of the institution.

The influential researches about student engagement in the past has been done by Chickering and Gamson (1987) which resulted in 7 good practice of student engagement principles in undergraduate education (Bangert, 2004; Glowatz \& Bofin, 2014; Junco et al., 2012; Kuh, 2003) which are:

1. Encouraging student-faculty contact

2. Encouraging cooperation among students

3. Encouraging active learning

4. Giving prompt feedback

5. Emphasising time on task

6. Communicating high expectations

7. Respecting diverse talents and ways of learning

Student engagement level will affect students' interaction with their friends and groups, adapt to university environment, and get the complete satisfaction (Kuh, 2003; McCarthy \& Kuh, 2006).

Student engagement today is heavily related with social media usage since social media popularity among students is a global trend and has the potential to be used for education (Selwyn, 2007; Bangert 2004; Siemens, 2004; McEwan, 2011, Glowatz \& O'Brien, 2013; Mazer et al., 2007; Junco et al., 2012; Glowatz \& Bofin, 2014). The nature of social media information like Facebook and Twitter allows student to create a different leaning experience a hybrid of formal and non-formal learning experience (McEwan, 2011). This happens because students prefer digital communication than face-to-face communication (McEwan, 2011; Ford 
et al., 2011), Students like to use social media as a part of their learning experience, and it contributes to their satisfaction (Griffiths \& Wall, 2011; Subramanian, 2012).

\subsubsection{Criteria and Sub Criteria}

For criteria, there are 2 factors, which are Information Quality and Service Quality to examine social media implementation quality.

\subsubsection{Information Quality}

Information Quality is the strength of the content embedded in an informational message, informational quality is the value of the (informational) output produced by a user as perceived by other users. (McKinney, Yoon \& Zahedi, 2002; Yeap, Ignatius \& Ramayah, 2014).

\subsubsection{Service Quality}

Service Quality is an ability measurement of providing services that fit with customer demand (Kim \& Nitecki, 2014; Lewis \& Booms, 1983; Sorooshian, Salimi, Salehi, Nia \& Asfaranjan, 2013).

Information Quality has 5 sub criteria, which are relevance, timeliness, accuracy, comprehensiveness, and usefulness. On the other hand, Service Quality has 4 sub criteria, which are efficiency, system availability, fulfillment, and privacy. The description of each sub criteria can be seen in Table 1 below.

Sub Criteria

\begin{tabular}{|l|l|}
\hline \multicolumn{2}{|c|}{ Information Quality (Yeap et al., 2014) } \\
\hline Relevance & The extent to which the informational content is appropriate and applicable. \\
\hline Timeliness & The extent to which the informational content is current and timely. \\
\hline Accuracy & The extent to which the informational content is correct and reliable. \\
\hline Comprehensiveness & The extent to which the informational content has sufficient breadth and depth. \\
\hline Usefulness & The extent to which the informational content is valuable, informative and helpful. \\
\hline \multicolumn{2}{|l|}{ Service Quality (Kim \& Nitecki, 2014) } \\
\hline Efficiency & The speed and ease in accessing and using provided service \\
\hline System Availability & The correct technical function from the platform \\
\hline Fulfillment & $\begin{array}{l}\text { Service operational to customers, such as accurate scheduling, respond to customer, value } \\
\text { information is delivered on time, etc. }\end{array}$ \\
\hline Privacy & The extent to which the platform security is maintained and protect user information. \\
\hline
\end{tabular}

Table 1. Sub Criteria description 


\subsubsection{Alternatives}

There are 2 levels of alternatives, which are student engagement and social media. Student engagement has 7 factors which already mentioned previously.

Social media alternative provided in this research is gained by spreading the data of 580 students from 58 private universities (10 from each university) and resulted in the fact that there are 10 social media used by these students, which are Facebook, Twitter, Path, LINE, Instagram, LinkedIn, YouTube, Podcast, Blog, and Wiki.

\subsubsection{Hierarchy}

The goal, which is social media preference to improve student engagement in university, is broken down into two criteria, which are information quality and service quality. Information quality is broken down into 5 sub criteria, which are relevance, timeliness, accuracy, comprehensiveness, and usefulness. On the other hand, service quality is broken down into 4 criteria, which are efficiency, system availability, fulfillment, and privacy. The sub criteria then broken down into 2 alternative levels. The first level is regarding student engagement, and the second level is regarding the social media used.

This Figure 2 is the hierarchy of social media usage preference.

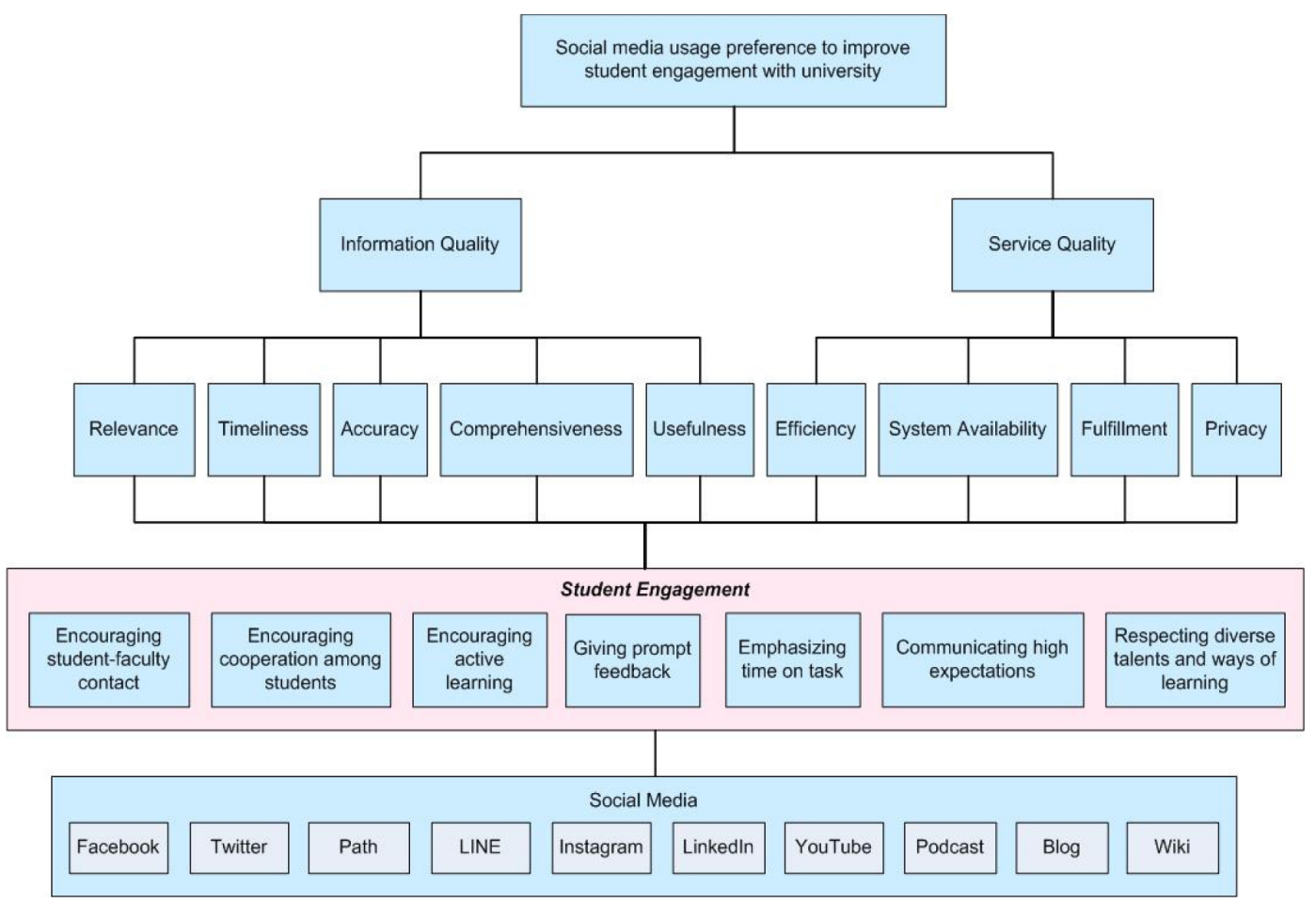

Figure 2. Hierarchy of social media usage preference 


\subsection{Analysis Method}

There are a lot of methods in multiple criteria decision making (MCDM), Entropy and TOPSIS are two commonly-used methods to rank and pick from the alternatives through Euclidean distance measurement (Zhang, Gu, Gu \& Zhang, 2011).

\subsubsection{Entropy}

According to Asl, Khalilzadeh, Youshanlouei and Mood (2012), entropy has special concept in physics, social, and information theory. Entropy is the criteria to express distributed probability distribution especially in open question questionnaire, and shanon entropy is the best method to measure the special criteria and one of the Multiple Criteria Decision Making methods. Shannon entropy method is objective because it's based on mathematic calculation that has been created by Shannon (1984).

Shannon (1984) explains that entropy method can be used for something other than estimating data quantity. It can also be used to objectively calculate the relative measure of information (Hsu \& Hsu, 2006). Entropy in information theory is a criteria for uncertainty, represented by discrete probability distribution (Jaynes, 1957 in Hsu \& Hsu, 2006). Some researches has used entropy method to measure the attributes such as case study on raw material supplier (Wardhani, Usadha \& Irawan, 2012), and evaluation on water quality in reservoir (Zou, Yun \& Sun, 2006).

The measuring steps with entropy method are as following:

1. All decision making has to give value that shows the importance of certain criteria on the decision making. Each decision making can measure according to its preference.

2. Reduce each number with the most ideal one. The result is called $X_{i j}$.

3. Divide each $X_{i j}$ with total amount of value in the criteria to get $P_{i j}$ matrix.

$$
P_{i j}=\frac{X_{i j}}{\sum_{i=1}^{m} X_{i j}}, \quad \forall i, j .
$$

Where $m=$ the number of decision makers

4. Calculate entropy value for each criteria with this formula

$$
\begin{gathered}
E_{j}=-k \sum_{i=1}^{m} P_{i j} \ell n P_{i j}, \quad \forall j . \\
\text { Where } k=\frac{1}{\ell n m}
\end{gathered}
$$


Next, calculate dispersion of each criteria with the following formula.

$$
d_{j}=1-E_{j}, \quad \forall j .
$$

Assuming the total value is 1 , to get the value of each criteria, the dispersion value has to be normalized. Therefore

$$
W_{j}=\frac{d_{j}}{\sum_{j=1}^{n} d_{j}}, \quad \forall j .
$$

Where $n=$ the number of criteria

\subsubsection{TOPSIS (Technique for Order Preference by Similarity to Ideal Solution)}

TOPSIS is a decision multi criteria decision making method that uses the principles that the selected alternatives has to have the shortest distance from the positive ideal solution and the longest distance from the negative ideal solution (Hsu \& Hsu, 2006). This method is first introduced by Hwang and Yoon (1981) by considering 2-ways solution. The first way is positive ideal solution that is obtained from the best value of each attribute. The second one is negative ideal solution, from the worst value from each attribute. TOPSIS is commonly used to conduct evaluation, as done in Gosh's research on evaluating faculty performance (Ghosh, 2011). The weakness of TOPSIS is before being able to use it, the attribute has to be given a weight. Therefore, the entropy method is required to get the weight from each criteria. The combination of these 2 methods has been done by some previous researches such has Hsu and Hsu which used entropy and TOPSIS to select the suitable Medical Information System for a clinic (Hsu \& Hsu, 2006).

The steps of TOPSIS algorithm is as following:

1. Build a normalized decision matrix using the formula

$$
\gamma_{i j}=\frac{\chi_{i j}}{\sqrt{\sum_{i=1}^{m} \chi_{i j}^{2}}} .
$$

In normalization matrix, $i$ is alternative solution, $j$ is criteria/factor, and $x_{i j}$ is the $i$ solution with $j$ criteria.

2. Build a weighted normalized decision matrix with the weight value coming from entropy measurement result, resulting in $v$ matrix value normalization 


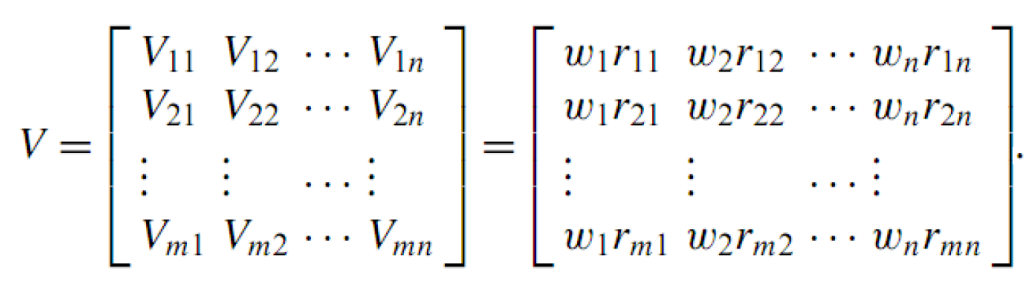

3. Decide positive ideal solution and negative ideal solution. The positive ideal solution is noted with $A^{*}$, and negative ideal solution is noted with $A^{-}$. Both are obtained with this formula:

$$
\begin{aligned}
A^{*} & =\left\{\left[\max _{i} V_{i j} \mid j \in J\right],\left[\min _{i} V_{i j} \mid j \in J^{\prime}\right] \mid i=1,2, \ldots, m\right\} \\
& =\left\{V_{1}^{*}, V_{2}^{*}, \ldots, V_{j}^{*}, \ldots, V_{n}^{*}\right\}, \\
A^{-} & =\left\{\left[\min _{i} V_{i j} \mid j \in J\right],\left[\max _{i} V_{i j} \mid j \in J^{\prime}\right] \mid i=1,2, \ldots, m\right\} \\
& =\left\{V_{1}^{-}, V_{2}^{-}, \ldots, V_{j}^{-}, \ldots, V_{n}^{-}\right\} .
\end{aligned}
$$

4. Calculate separation or distance value between each alternative solution from $A^{*}$ and $A^{-}$ with this formula:

$$
\begin{aligned}
& S_{i}^{*}=\sqrt{\sum_{j=1}^{n}\left(V_{i j}-V_{i}^{*}\right)^{2}}, \quad i=1,2, \ldots, m, \\
& S_{i}^{-}=\sqrt{\sum_{j=1}^{n}\left(V_{i j}-V_{i}^{-}\right)^{2}}, \quad i=1,2, \ldots, m .
\end{aligned}
$$

5. Calculate the relative proximity on ideal solution

$$
C_{i}^{*}=\frac{S_{i}^{-}}{S_{i}^{*}+S_{i}^{-}} .
$$

6. Sort the $C_{i}^{*}$ value. The best solution is the one that has the shortest distance to the positive ideal solution and farthest distance to the negative ideal solution.

\section{Discussions and Results}

\subsection{Data Collection}

The questionnaire has 2 parts:

- Criteria and sub criteria weight calculation by using likert scale (1 - 6). The weight calculation is done according to the importance level. 
- Alternative ranking using the scale of $1-10$.

The questionnaire is distributed to students in 58 private universities in Jakarta. The questionnaire was sent to the 58 private university campuses. Those who have been asked to fill the questionnaire will be asked to distribute the questionnaire their friends. From the questionnaire data collected, there are 1060 questionnaire, but only 1021 questionnaire that are counted as valid included in the calculation.

\subsection{Respondent Demography}

From the questionnaire data, there are some descriptive data such as age, gender, university name, major taken, education level, semester at the time filling the questionnaire, number of social media account possessed, and the most used social media. The descriptive data summary can be seen in the Table 2 below.

From descriptive data summary for gender distribution, it is seen that there are more male respondents than female respondents. Respondents' age ranged from 17 to 30 years old with the majorities are 17 to 20 years old. For education level, almost all of them are taking undergraduate program (S1), and only one taking diploma (D4). From the semester data, it's equally distributed in 2, 4, 6, and 8 semester, with only 9 in semester 10 . From the number of social media account possessed, respondents generally have 4 to 6 accounts. This proofs that the social media is a thing for teenager. Some even have more than 10 accounts. 4 to 6 social media accounts is still sensible since each has different functions. From the Table 2 above, it is seen that LINE is the most used social media. Communicating with this social media is also easy, with only phone number required and enable to have personal interaction. The next one is Facebook, which is still widely used thanks to its complete features and games. The next one is Path, which is similar to Facebook but has the "close" taste because it limits the number of contacts up to only 150, way below Facebook limits of 5000. In Path, you have to be selective in choosing your friends. 


\begin{tabular}{|c|c|c|c|}
\hline \multicolumn{2}{|c|}{ Description } & \multicolumn{2}{|c|}{ Total } \\
\hline \multirow{2}{*}{ Gender } & Male & 569 & \multirow{2}{*}{1,021} \\
\hline & Female & 452 & \\
\hline \multirow{4}{*}{ Age } & $17-20$ years old & 640 & \multirow{4}{*}{1,021} \\
\hline & $21-24$ years old & 346 & \\
\hline & $25-29$ years old & 34 & \\
\hline & $>=30$ years old & 1 & \\
\hline \multirow{2}{*}{ Educational level } & Undergraduate (S1) & 1020 & \multirow{2}{*}{1,021} \\
\hline & Diploma (D4) & 1 & \\
\hline \multirow{5}{*}{ Semester level } & 2 & 218 & \multirow{5}{*}{1,021} \\
\hline & 4 & 289 & \\
\hline & 6 & 273 & \\
\hline & 8 & 232 & \\
\hline & 10 & 9 & \\
\hline \multirow{4}{*}{$\begin{array}{l}\text { The number of social } \\
\text { media accounts } \\
\text { owned by } \\
\text { respondents }\end{array}$} & $1-3$ & 337 & \multirow{4}{*}{1,021} \\
\hline & $4-6$ & 608 & \\
\hline & $7-9$ & 68 & \\
\hline & $>=10$ & 8 & \\
\hline \multirow{17}{*}{$\begin{array}{l}\text { The number of social } \\
\text { media is most often } \\
\text { used by respondents }\end{array}$} & LINE & 247 & \multirow{17}{*}{1,021} \\
\hline & Facebook & 201 & \\
\hline & Path & 189 & \\
\hline & BBM & 179 & \\
\hline & Instagram & 117 & \\
\hline & Twitter & 46 & \\
\hline & Snapchat & 13 & \\
\hline & Whatsapp & 9 & \\
\hline & Ask.fm & 5 & \\
\hline & Waze & 4 & \\
\hline & You Tube & 2 & \\
\hline & Kakao Talk & 2 & \\
\hline & Bee Talk & 2 & \\
\hline & Tinder & 2 & \\
\hline & LinkedIn & 1 & \\
\hline & We chat & 1 & \\
\hline & Omegle & 1 & \\
\hline
\end{tabular}

Table 2. Descriptive Data Summary 


\subsection{Research Results}

The first step of data analysis is calculating the weight of importance of each criteria calculated with entropy method. The result can be seen in the Table 3 below.

\begin{tabular}{|c|c|c|}
\hline No & Entropy & Criteria \\
\hline 1 & 0.571565215 & Information Quality \\
\hline 2 & 0.428434785 & Service Quality \\
\hline
\end{tabular}

Table 3. Entropy value for criteria

Next, calculate the weight of importance of each sub-criteria, also calculated with entropy method. The result can be seen in the Table 4 below.

\begin{tabular}{|c|c|c|}
\hline No & Entropy & Sub Criteria for Information Quality \\
\hline 1 & 0.352076301 & Usefulness \\
\hline 2 & 0.299821450 & Comprehensiveness \\
\hline 3 & 0.190852143 & Accuracy \\
\hline 4 & 0.087435174 & Timeliness \\
\hline 5 & 0.069814932 & Relevance \\
\hline
\end{tabular}

\begin{tabular}{|c|c|c|}
\hline No & Entropy & Sub Criteria for Service Quality \\
\hline 1 & 0.309683282 & System Availability \\
\hline 2 & 0.297247652 & Efficiency \\
\hline 3 & 0.274931554 & Fulfillment \\
\hline 4 & 0.118137512 & Privacy \\
\hline
\end{tabular}

Table 4. Entropy value for sub-criteria

Next, calculate the ranking of student engagement alternative with TOPSIS. The result can be seen in the Table 5 below.

\begin{tabular}{|c|c|}
\hline Student Engagement & TOPSIS \\
\hline Cooperation & 0.607419255 \\
\hline Learn & 0.604900691 \\
\hline Expectation & 0.593261712 \\
\hline Contact & 0.589465169 \\
\hline Talents & 0.573278656 \\
\hline Feedback & 0.558134166 \\
\hline Time & 0.425887436 \\
\hline
\end{tabular}

Conclusion:

Cooperation $>$ Learn $>$ Expectation $>$ Contact $>$ Talents $>$ Feedback $>$ Time

Table 5. TOPSIS value for student engagement alternative 
The last step is calculating the ranking of social media alternative with TOPSIS. The result can be seen in the Table 6 below.

\begin{tabular}{|c|r|}
\hline Social Media & \multicolumn{1}{|c|}{ TOPSIS } \\
\hline LINE & 1 \\
\hline Facebook & 0.736649451 \\
\hline Twitter & 0.299037858 \\
\hline Wiki & 0.230418098 \\
\hline Blog & 0.22977594 \\
\hline Instagram & 0.211628073 \\
\hline You Tube & 0.185243939 \\
\hline Path & 0.163957155 \\
\hline LinkedIn & 0.158532507 \\
\hline Podcast & 0 \\
\hline
\end{tabular}

Conclusion:

LINE $>$ Facebook $>$ Twitter $>$ Wiki $>$ Blog $>$ Instagram $>$ You Tube $>$

Path $>$ LinkedIn $>$ Podcast

Table 6. TOPSIS value for social media alternative

From the tables above, it can be concluded that respondents prioritize information quality compared to service quality. This is inline with previous researches stated that social media usage is heavily reliant on information quality because the quality of information can affect someone's decision (Agarwal \& Yiliyasi, 2010; Emamjome, Rabaa'i, Gable \& Bandara, 2013). Respondents also prioritize the usage and completeness of information, before considering system availability, efficiency, and fulfillment of the service to improve student engagement with university.

Good information quality and service quality will directly impact student engagement. The students also said that the most important factor for them is encouraging cooperation among students, followed by encouraging active learning and communicating high expectations. Then, it respectively followed by encouraging student-faculty contact, respecting diverse talents and ways of learning, giving prompt feedback, and emphasizing time on task. The cooperation between students is really important in supporting active learning and good relationship between students and their lecturers. University also has to pay attention on students' expectation on all processes and facility and also provide a good and accurate handling on feedback given by the students. Respecting the diversity and difference among students and lecturers both in individual behavior or the way of learning is a must. Good time management can also affect students' success (van der Velden, Pool, Lowe Naidoo \& Pimentel-Botas, 2013).

The most important social media used by the students to improve student engagement with university is LINE, followed by Facebook, Twitter, and then Wiki, Blog, Instagram, YouTube, Path, 
LinkedIn, and Podcast. This is inline with the fact that LINE is currently the most "happening" social media among teenagers and its connectivity is easy, with only phone number required and enable to have personal interaction. LINE also has entertainment features which students like, such as sticker, image, video, etc. Facebook is the next preferred social media thanks to its complete features and applications, and also has the huge contact capacity (up to 5000 contacts), making it still the social media of choice for student engagement (Bosch, 2009; Glowatz \& O’Brien, 2013; Junco, 2011; Mazer et al., 2007; McEwan, 2011; Muñoz \& Towner, 2009; Selwyn, 2007; van der Velden et al., 2013). Twitter is a social media with microblogging form that is used to get short information to update the user. Twitter is also considered important by the students to improve student engagement with university because the easy-toaccess information and flexibility of it (Hussey, 2011; Junco et al., 2012; van der Velden et al., 2013). In addition, Twitter is also an educational tool that can be used for classroom community, exploring collaborative writing, reader response, explore the potential of microblogging in formal and informal settings, collaboration across schools and countries, project management, a tool for assessing opinion, examining consensus, looking for outlying ideas, facilitating virtual classroom discussion by using @username, creating a learning experience, facilitating a personal learning network in the edublogosphere, etc (Grosseck \& Holotescu, 2008).

\section{Implications}

\subsection{Research Implications}

The implication for science is social media role is not only to create student engagement in the learning process, but also other aspects stated by Chickering and Gamson (1987). Information quality and service quality can be used to examine the social media implementation quality (Yeap et al., 2014; Kim \& Nitecki, 2014).

\subsection{Practical Implications}

The Social CRM channel shifting from electronic into social media shows that social media role for university is really important. With social media, university can easily communicate with their students. Good communications will impacts on the student engagement improvement with the university. A good social media management has been an issue that has to be solved by university by creating a unit or delegate a person that can manage the social media quickly and accurately in order to make the students felt they get the good service. In addition to that, with weighting and ranking method, the preferred social media used by students can be identified. 


\section{Conclusions}

This research shows that students prioritize information quality more than service quality in improving student engagement with university. The usefulness and comprehensiveness of information is something that is seen important because complete information will be really useful to support students success it their study. Other than system availability, efficiency and service fulfillment are also seen important by the students. In the student engagement itself, the factors that are seen important by the students are cooperation among students, active learning, and attention on students' expectation. This research can answer research question that is created, which is which social media channel preferred by the students to improve their student engagement in university. Respectively, the preferred social media are LINE, Facebook, Twitter, Wiki, Blog, Instagram, YouTube, Path, LinkedIn, and Podcast.

University customers are students and alumni, thus future research conducted is to analyze alumni social media preference to improve alumni engagement with university.

\section{References}

Agarwal, N., \& Yiliyasi, Y. (2010). Information Quality Challenges in Social Media. Paper presented at the International Conference on Information Quality (ICIQ). University of Arkansas at Little Rock (UALR). Available at: http://mitiq.mit.edu/ICIQ/Documents/IQ\%20Conference \%202010/Papers/3A1_IQChallengesInSocialMedia.pdf

Askool, S.S., \& Nakata, K. (2010, June). Scoping Study to Identify Factors Influencing the Acceptance of Social CRM. Proceedings of International Conference on Management of Innovation and Technology (ICMIT). Singapore. 1055-1060. http://dx.doi.org/10.1109/ICMIT.2010.5492888

Asl, M.B., Khalilzadeh, A., Youshanlouei, H.R., \& Mood, M.M. (2012). Identifying and ranking the effective factors on selecting Enterprise Resource Planning (ERP) system using the combined Delphi and Shannon Entropy approach. Procedia - Social and Behavioral Sciences, 41, 513-520. http://dx.doi.org/10.1016/j.sbspro.2012.04.063

Bangert, A.W. (2004). The Seven Principles of Good Practice: A framework for evaluating on-line teaching. The Internet and Higher Education, 7(3), 217-232. http://dx.doi.org/10.1016/j.iheduc.2004.06.003

Bofin, L. (2013). The Impact of Social Media \& eLearning Applications on Student, Engagement-The benefits of introducing social media \& eLearning applications to classroomtaught modules. UCD Michael Smurfit Graduate Business School, College Of Business \& Law, University College Dublin. 
Bosch, T.E. (2009). Using online social networking for teaching and learning: Facebook use at the University of Cape Town. Communicatio: South African Journal for Communication Theory and Research, 35(2), 185-200. http://dx.doi.org/10.1080/02500160903250648

Chickering, A.W., \& Gamson, Z.F. (1987). Seven Principles for Good Practice in Undergraduate Education. AAHE Bulletin, 3-7. Available at: http://www.aahea.org/articles/sevenprinciples1987.htm

Christenson, S.L., Reschly, A.L., \& Wylie, C. (Eds.) (2012). Handbook of research on student engagement. New York, NY: Springer.

http://dx.doi.org/10.1007/978-1-4614-2018-7

DeLone, W.H., \& McLean, E.R. (2003). The DeLone \& McLean Model of Indormation Systems Success: A Ten-Year Update. Journal of Management Information Systems, 19(4), 9-30.

Doyle, A. (2012). Social Media Definition. Available online at: http://jobsearch.about.com/od/networking/g/socialmedia.htm

Emamjome, F.F., Rabaa'i, A.A., Gable, G.G., \& Bandara, W.W. (2013). Information Quality in Social Media: a Conceptual Model. In Lee, J-N., Mao, J-Y., \& Thong, J. (Eds.). Proceedings of the Pacific Asia Conference on Information Systems (PACIS 2013). AIS Electronic Library (AISel), Jeju Island, Korea.

Finn, J., \& Zimmer, K. (2012). Student engagement: What is it? Why does it matter? In Christenson, S.L., Reschly, A.L., \& Wylie, C. (Eds.). Handbook of research on student engagement, New York, NY: Springer. pp. 97-132. http://dx.doi.org/10.1007/978-1-4614-2018-7_5

Ford, N., Bowden, M., \& Beard, J. (2011). Learning together: using social media to foster collaboration in higher education. In Wankel, L.A., \& Wankel, C. (Eds.). Higher Education Administration with Social Media (Cutting-edge Technologies in Higher Education), Volume 2 Emerald Group Publishing Limited. 105-126. http://dx.doi.org/10.1108/s2044-9968(2011)0000002009

Ghosh, D.N. (2011). Analytic Hierarchy Process \& TOPSIS Method to Evaluate Faculty Performance in Engineering Education. UNIASCIT, 1(2), 63-70.

Glowatz, M., \& Bofin, L. (2014). Enhancing Student Engagement Through Social Media A School of Business Case Study. BLED 2014 Proceedings. Paper 37. Available at: http://aisel.aisnet.org/bled2014/37 http://dx.doi.org/10.4108/el.1.4.e4

Glowatz, M., \& O'Brien, O. (2013). Facebook in an Academic Environment: Advancing Practice from Information - Sharing to Collaboration and Innovation (ICI). BLED 2013 Proceedings. Paper 11. Available at: http://aisel.aisnet.org/bled2013/11

Greenberg, P. (2010). CRM Customer Relationship Management, Social CRM Strategies, Tools, and Techniques for Engaging Your Customers, at the Speed of Light. Fourth Edition. McGraw-Hill Osborne. 
Griffith, P., \& Wall, A. (2011). Social Media use by enrollment management. In Wankel, L.A., \& Wankel, C. (Eds.). Higher Education Administration with Social Media (Cutting-edge Technologies in Higher Education), Volume 2. Emerald Group Publishing Limited. 49-67. http://dx.doi.org/10.1108/s2044-9968(2011)0000002006

Grosseck, G., \& Holotescu, C. (2008). Can we use Twitter for Educational Activities? Proceedings of The 4th International Scientific Conference eLSE "eLearning and Software for Education", Bucharest, 17-18 April.

Hsu, P.-F., \& Hsu, M.-G. (2006). Optimizing the Information Outsourcing Practices of Primary Care Medical Organizations Using Entropy and TOPSIS. Hsin Chu City: Yuanpei University.

Hussey, J. (2011). Twitter in higher education: From application to alumni relations. In L.A. Wankel, \& Ch. Wankel (Eds.), Higher Education Administration with Social Media (Cuttingedge Technologies in Higher Education, Volume 2, pp. 249-272). Emerald Group Publishing Limited. http://dx.doi.org/10.1108/s2044-9968(2011)0000002016

Hwang, C.L., \& Yoon, K. (1981). Multiple Attribute Decision Making Methods and Applications. Germany: Springer, Berlin Heidelberg. http://dx.doi.org/10.1007/978-3-642-48318-9

Jaynes, E.T. (1957). Information theory and statistical mechanics. Physical Review, 106(4), 620-630. http://dx.doi.org/10.1103/PhysRev.106.620

Junco, R. (2011). The relationship between frequency of Facebook use, participation in Facebook activities, and student engagement. Computers \& Education, 58(2011), 162-171. http://dx.doi.org/10.1016/j.compedu.2011.08.004

Junco, R., Elavsky, C.M., \& Heiberger, G. (2012). Putting twitter to the test: Assessing outcomes for student collaboration, engagement and success. British Journal of Educational Technology, 44(2), 273-287. http://dx.doi.org/10.1111/j.1467-8535.2012.01284.x

Kaplan, A.M., \& Haenlein, M. (2010). Users of the World, Unite! The Challenges and Opportunities of Social Media. Business Horizons, 53(1), 59-68. http://dx.doi.org/10.1016/j.bushor.2009.09.003

Khan, G.F. (2013). Social media-based systems: an emerging area of information systems research and practice. Scientometrics, 95(1), 159-180. http://dx.doi.org/10.1007/s11192-012-0831-5

Kim, H.M. \& Nitecki, D.A. (2014). A Proposed Scale for Measuring the Quality of Social Media Services: An E-S-QUAL Approach. ASIST 2014 Proceedings. November 1-4. Seattle, USA. http://dx.doi.org/10.1002/meet.2014.14505101104 
Kuh, G.D. (2003). What We're Learning About Student Engagement From NSSE: Benchmarks for Effective Educational Practices. Change: The Magazine of Higher Learning, 35(2), 24-32. http://dx.doi.org/10.1080/00091380309604090

Lawson, M.A., \& Masyn, K.E. (2015). Analyzing profiles, predictors, and consequences of student engagement dispositions. Journal of School Psychology, 53, 63-86. http://dx.doi.org/10.1016/j.jsp.2014.11.004

Lewis, R.C., \& Booms, B.H. (1983). The marketing aspects of service quality. In Berry, L., Shostack, G., \& Upah, G. (Eds.). Emerging perspectives on services marketing. American Marketing Association Chicago. 99-104.

Malthouse, E.C., Haenlein, M., Skiera, B., Wege, E., \& Zhang, M. (2013). Managing Customer Relationships in the Social Media Era: Introducing the Social CRM House. Journal of Interactive Marketing, 27, 270-280. http://dx.doi.org/10.1016/j.intmar.2013.09.008

Mazer, J.P., Murphy, R.E., \& Simonds, C.J. (2007). I'll See You On "Facebook": The Effects of Computer-Mediated Teacher Self-Disclosure on Student Motivation, Affective Learning, and Classroom Climate. Communication Education, 56(1), 1-17. http://dx.doi.org/10.1080/03634520601009710

McCarthy, M., \& Kuh, G.D. (2006). Are Students Ready for College? What Student Engagement Data Say. Phi Delta Kappan, 87(9), 664-669. http://dx.doi.org/10.1177/003172170608700909

McEwan, B. (2011). Hybrid engagement: How Facebook helps and hinders students' social integration. In Wankel, L.A., \& Wankel, C. (Eds.). Higher Education Administration with Social Media (Cutting-edge Technologies in Higher Education), Volume 2. Emerald Group Publishing Limited. 3-23. http://dx.doi.org/10.1108/s2044-9968(2011)0000002004

McKinney, V., Yoon, K., \& Zahedi, F. (2002). The Measurement of Web-Customer Satisfaction: An Expectation and Disconfirmation Approach. Information System Research, 13(3), 296-315. http://dx.doi.org/10.1287/isre.13.3.296.76

Meyliana, Hidayanto, A.N., \& Budiardjo, E.B. (2015). Social Media Adoption for Social CRM in Higher Education: An Insight from Indonesian Universities. International Journal of Synergy and Research. In Press.

Mohan, S., Choi, E., \& Min, D. (2008). Conceptual Modeling of Enterprise Application System Using Social Networking and Web 2.0 "Social CRM System". Proceedings of International Conference on Convergence and Hybrid Information Technology (ICHT '08). Daejeon, South Korea: IEEE. pp. 237-244. http://dx.doi.org/10.1109/ichit.2008.263 
Mosadegh, M.J., \& Behboudi, M. (2011). Using Social Network Paradigm for Developing a Conceptual Framework in CRM. Australian Journal of Business and Management Research, $1(4), 63-71$.

Muñoz, C.L. \& Towner, T.L. (2009). Opening Facebook: How to Use Facebook in the College Classroom. Paper presented at the 2009 Society for Information Technology and Teacher Education Conference. Charleston, South Carolina. Available at: http://www46.homepage.villanova.edu/john.immerwahr/TP101/Facebook.pdf

Patel. K. (2013). Incremental Journey for World Wide Web: Introduced with Web 1.0 to Recent Web 5.0 - A Survey Paper. International Journal of Advanced Research in Computer Science and Software Engineering, 3(10), 410-417.

Rumberger, R., \& Rotermund, S. (2012). The relationship between engagement and high school drop-out. In Christenson, S.L., Reschly, A. L., \& Wylie, C. (Eds.). Handbook of research on student engagement. New York, NY: Springer. 491-514. http://dx.doi.org/10.1007/978-1-46142018-7_24

Schouten, P. (2011). Using social media in study abroad. In Wankel, L.A., \& Wankel, C. (Eds.). Higher Education Administration with Social Media (Cutting-edge Technologies in Higher Education), Volume 2. Emerald Group Publishing Limited. 127-145. http://dx.doi.org/10.1108/s2044-9968(2011)0000002010

Seeman, E.D., \& O'Hara, M. (2006). Customer relationship management in higher education: Using information systems to improve the student-school relationship. Campus-Wide Information Systems, 23(1), 24-34. http://dx.doi.org/10.1108/10650740610639714

Selwyn, N. (2007). Screw blackboard... do it on Facebook!: An investigation of students' educational use of Facebook. Presented at the Pole 1.0 - Facebook Social Research Symposium, University of London. Available at: http://startrekdigitalliteracy.pbworks.com/f/2g19b89ezl6ursp6e749.pdf

Shannon, C. (1948). A Mathematical Theory of Communication. The Bell System Technical Journal, 27, 379-423. http://dx.doi.org/10.1002/j.1538-7305.1948.tb01338.x

Siemens, G. (2004). Connectivism: A Learning Theory for the Digital Age. Elearnspace. Available at: http://www.elearnspace.org/Articles/connectivism.htm

Sorooshian, S., Salimi, M., Salehi, M., Nia, N.B., \& Asfaranjan, Y.S. (2013). Customer experience about service quality in online environment: A case of Iran. Procedia - Social and Behavioral Sciences, 93, 1681-1695. http://dx.doi.org/10.1016/j.sbspro.2013.10.101 
Subramanian, P. (2012). Towards a massive online education: A Business Model Innovation for Elite Universities in the UK. Imperial College Business School, Imperial College London. Available at: http://prabhus.com/media/Subramanian-P-2012-WEMBA-thesis.pdf

Tapp, A., Hicks, K., \& Stone, M. (2004), Direct and database marketing and customer relationship management in recruiting students for higher education. International Journal of Nonprofit and Voluntary Sector Marketing, 9(4), 335-345. http://dx.doi.org/10.1002/nvsm.258

Trowler, V. (2010). Student engagement literatura review. The Higher Education Academy. Available at: https://www.heacademy.ac.uk/sites/default/files/studentengagementliteraturereview 1.pdf

van der Velden, G.M., Pool, A.D., Lowe, J.A., Naidoo, R., \& Pimentel-Botas, P.C. (2013). Student Engagement in Learning and Teaching Quality Management. A Good Practice Guide for Higher Education Providers and Student s' Unions. University of Bath. Available at: http://www.bath.ac.uk/learningandteaching/pdf/student_engagement/Good_Practice_Guide_11.9.2013.pdf

Wardhani, I.K., Usadha, I.G., \& Irawan, M.I. (2012). Seleksi Supplier Bahan Baku dengan Metode TOPSIS Fuzzy MADM (Studi Kasus PT. Giri Sekar Kedaton, Gresik). Jurnal Sains dan Seni Pomits, 1(1), 1-6.

Wise, E.K., \& Shorter, J.D. (2014). Social Networking and The Exchange of Information. Issues in Information Systems, 15(II), 103-109.

Yeap, J.A.L., Ignatius, J., \& Ramayah, T. (2014). Determining consumers' most preferred eWOM platform for movie review: A fuzzy analytic hierarchy process approach. Computers in Human Behavior, 31, 250-258. http://dx.doi.org/10.1016/j.chb.2013.10.034

Zhang, H., Gu, C-I., Gu, L-W., \& Zhang, Y. (2011). The evaluation of tourism destination competitiveness by TOPSIS \& information entropy - A case in the Yangtze River Delta of China. Tourism Management, 32, 443-451. http://dx.doi.org/10.1016/j.tourman.2010.02.007

Zou, Z., Yun, Y., \& Sun, J. (2006). Entropy method for determination of weight of evaluating indicators in fuzzy synthetic evaluation for water quality assessment. China: Beihang University.

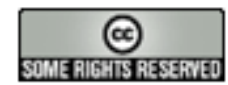

Article's contents are provided on an Attribution-Non Commercial 3.0 Creative commons license. Readers are allowed to copy, distribute and communicate article's contents, provided the author's and Journal of Industrial Engineering and Management's names are included. It must not be used for commercial purposes. To see the complete license contents, please visit http://creativecommons.org/licenses/by-nc/3.0/. 